Limnol. Rev. (2017) 17, 4: 207-214

\title{
Zooplankton communities in three adjacent softwater lobelia lakes of slightly differentiated morphology and trophic state
}

\author{
Natalia Kuczyńska-Kippen, Piotr Klimaszyk, Ryszard Piotrowicz \\ Department of Water Protection, Faculty of Biology, Adam Mickiewicz University, Umultowska 89, 61-614 Poznań, Poland, \\ e-mail: kippen@hot.pl (*corresponding author); pklim@amu.edu.pl; ryszardp@amu.edu.pl
}

\begin{abstract}
The paper presents the results of an investigation of physical-chemical features of water as well as rotifer and crustacean abundance and diversity measures, relating to the taxonomic richness and species diversity index, in three lobelia lakes differing in trophic status and morphometric features. The main purpose of this study was to establish the diversity of zooplankton communities in the open water area of lobelia lakes, including extracting species common for each lake and also to find environmental predictors which are responsible for the development of zooplankton communities. Despite the fact that the three studied lakes are of the same origin, located in the same vicinity and have generally similar environmental factors, zooplankton community structure revealed a great variation in reference to species diversity (only ca. $20 \%$ of the species were common for all lakes) and particularly in inhabiting species. Obrowo Lake had the most diverse assemblages of both rotifers and crustaceans compared to Modre and Pomysko lakes. In the taxonomic structure species that are rare for the Polish fauna, such as e.g. Holopedium gibberum and Heterocope appendiculata, occurred. Even though the examined lobelia lakes are ecosystems that undergo varying human-induced impacts, they still remain taxonomically very variable aquatic ecosystems, containing rare species of very high ecological status. The observed symptoms of deterioration of water quality, reflected in the zooplankton biocoenotic features, showed that the best conditions were attributed to Obrowo Lake in comparison with the two remaining lakes - Modre and Pomysko. Total nitrogen and chlorophyll a concentration were decisive for the distribution of zooplankton species in Pomysko and Obrowo lakes, while in case of Modre lake water reactivity and conductivity were of higher impact.
\end{abstract}

Key words: rotifers, crustaceans, environmental parameters, rare species, species diversity

\section{Introduction}

Lobelia lakes are softwater ecosystems that are characterised by specific features, including both biotic structure as well as hydrochemical and biotopic characteristics (Szmeja 1996). Such lakes should contain one or more characteristic small perennial plant species - Lobelia dortmanna L., Isoëtes lacustris L. and/or Littorella uniflora (L.) Asch. - named "isoetids". These lakes in EU member states are protected as a natural habitat, but unfortunately they are still in great danger of deterioration. Even a few decades ago many problems relating to conservation and evolutionary trends in this type of lake were emphasised (Kraska et al. 1996; Kraska and Piotrowicz, 2000). Today their existence is even more exposed to threat, thus any data that contributes to their recognition that will in the future lead to developing protective strategies, is very valuable.

The deterioration of lobelia lakes can be observed in the disappearance of isoetids and also further plant populations, e.g. stoneworts The studies conducted in the past 30 years have shown that the presence of only 6 out of 15 stonewort stands in Poland that were found in the mid-1970s, could recently be confirmed (Bociąg et al. 2011). This shows that $60 \%$ of sites and over $70 \%$ of species had disappeared completely from Polish lobelia lakes.

Plankton, along with its animal fraction - zooplankton, is a very important part of freshwater ecosystems. It can be specific for certain types of water body (Ruoppa et al. 2003). In lobelia lakes, nutrient-poor waters with very soft carbonate alkalinity will restrict the abundance and biomass of certain plankton species, namely certain zooplankton species. But at the same time typical species of algae and zooplankton can also be identified. Szeroczyńska and Zawisza (2011), conducting analyses on lake sediment cores from two northern lobelia lakes in Finland found twenty eight zooplankton species belonging to the following six families: Bosminidae, Daphniidae, Leptodoridae, Chydoridae, Macrothrici- 
dae and Sididae. Kraska et al. (2006) found that among species inhabiting three lobelia lakes the presence of Keratella serrulata, Polyarthra minor and Holopedium gibberum was identified. Over recent decades more data has been published on drastic long-term changes in physicochemical parameters of lobelia lakes as well as in the vegetation cover. Kraska et al. (2013) stated that in Lake Modre the water quality revealed a significant change, including a decrease in water transparency, oxygen deficits in the near-bottom layer, an increase in concentrations of nutrients as well as diminishment of the phytocoenosis of Lobelietum dortmannae.

As the deterioration of lobelia lakes has been noted elsewhere, e.g. due to changes in the trophic state of these lakes, changes in zooplankton community structure are also expected. Koff et al. (2016) observed that along with the increase of trophic state in the lobelia Lake Lohja there was a shift towards cladoceran species indicative of eutrophication, such as Bosmina longirostris, Chydorus sphaericus and Bosmina (E.) kessleri and also the disappearance of cladoceran species described as macrophyte-associated.

The aim of the present study was to determine conditions responsible for the development of zooplankton communities inhabiting three lobelia lakes differing in morphology and trophic state. Thus, this work was undertaken in order to: (i) assess the diversity of zooplankton communities in the open water area of lobelia lakes, (ii) extract species common for the studied ecosystems, and (iii) analyse the distribution of zooplankton species in reference to environmental parameters so as to find conditions that are specific for each lake.

Therefore, as the three studied lobelia lakes undergo various human-induced pressure we expect to find different predictors responsible for the development of diverse communities of zooplankton.

\section{Material and Methods}

The studied lakes are located in NW Poland in the Bytów Lakeland, with the following geographical coordinates: WGS 84 Modre lake: $54^{\circ} 15^{\prime} 49.3^{\prime \prime} \mathrm{N}$, $17^{\circ} 34^{\prime} 54.1^{\prime \prime} \mathrm{E}, \quad$ Obrowo Małe lake: $54^{\circ} 15^{\prime} 40^{\prime \prime} \mathrm{N}$, $17^{\circ} 35^{\prime} 15^{\prime \prime} \mathrm{E}$ and Pomysko lake: $54^{\circ} 15^{\prime} 30^{\prime \prime} \mathrm{N}, 17^{\circ} 34^{\prime} 30^{\prime \prime} \mathrm{E}$. The lakes are closed-drainage reservoirs with a small surface area and significant depth (Table 1). The catchments are small, steep sloped and only few times bigger than their surface. Catchments are covered with

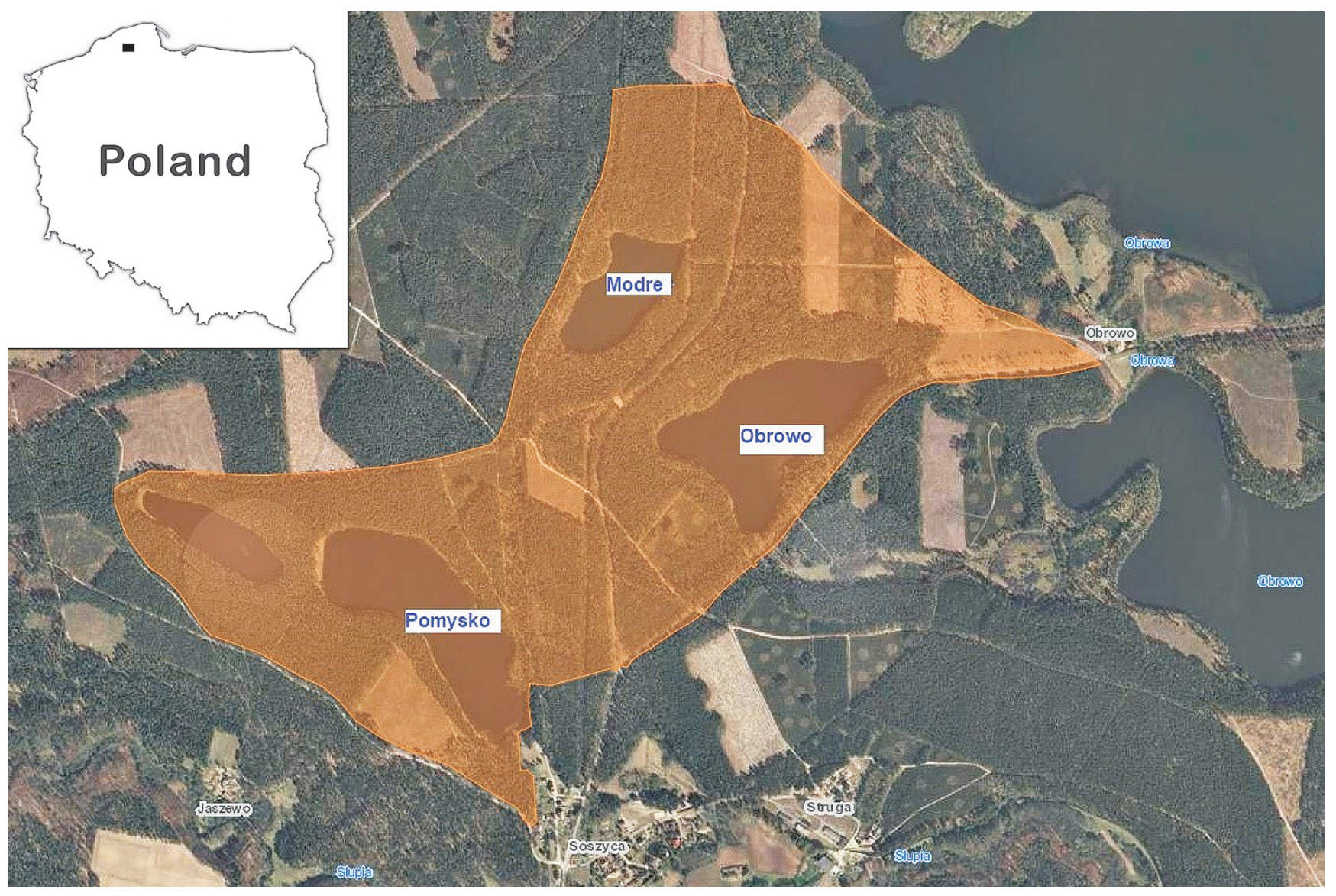

Fig. 1. Location of investigated lakes and the habitat area PLH220039 - Lobelia Lakes near Soszyca 
Table 1. Basic morphometric features of investigated lakes

\begin{tabular}{lcccc}
\hline Parameter & Unit & $\begin{array}{c}\text { Lake } \\
\text { Obrowo }\end{array}$ & $\begin{array}{c}\text { Lake } \\
\text { Modre }\end{array}$ & $\begin{array}{c}\text { Lake } \\
\text { Pomysko }\end{array}$ \\
\hline Surface area & {$\left[\mathrm{hm}^{2}\right]$} & 10.5 & 4.7 & 10.5 \\
\hline Max depth & {$[\mathrm{m}]$} & 12.2 & 13.7 & 6.4 \\
\hline Catchment size & {$\left[\mathrm{hm}^{2}\right]$} & 29.2 & 10.2 & 47.0 \\
\hline
\end{tabular}

coniferous forest and human pressure is low, mainly of recreational origin. The physical and chemical properties of water of the investigated lakes affect the specific composition of vegetation. Emergent plants are descent. Submerged macrophytes are characteristic of lobelia lakes, predominantly Lobelia dortmanna, Littorella uniflora and Isoetes lacustris, inhabiting the deepest part of the littoral. According to specific macrophyte composition and water features all the investigated lakes are representative of nature habitat 3110 according to the EU habitat directive, and are protected as habitat area PLH220039 - Lobelia Lakes near Soszyca (Fig. 1).

Laboratory work was performed following the Standard Methods for the Examination of Water and Wastewater (APHA 1992). Additionally, in the middle of the stratification period in the deepest part of the lakes: Secchi disc visibility and water temperature, oxygen concentration, $\mathrm{pH}$, and specific conductivity were measured with a multiparameter probe YSI 3500.

The study of the spatial distribution of zooplankton (rotifers and crustaceans) in the various thermal layers of water, including epilimnion, metalimnion and hy- polimnion was carried out during the summer season (August-September).

Samples of $20 \mathrm{dm}^{-3}$ volume were collected three times from each site. Zooplankton material was collected in triplicate and the mean abundance from the three samples was taken into the account for further analyses.Sampleswere concentrated using a planktonic net $(45 \mu \mathrm{m})$ and preserved immediately with $4 \%$ formaldehyde.

The dominating species were designated as those which reached a minimum of $10 \%$ of the total densities of each group of zooplankton (rotifers and crustaceans).

The Kruskal-Wallis test was applied in order to determine the effect of the lake on zooplankton biocoenotic parameters $(\mathrm{N}=24)$. Principal component analysis (PCA) was applied to identify the effect of the lake and the environmental factors on the abundance of zooplankton dominating species. This analysis was performed using the STATISTICA v. 10 software package.

To define the species diversity of particular groups of zooplankton in each lake the Shannon-Weaver index was applied (Margalef 1957).

\section{Results}

The studied lakes are typical soft water lakes due to low concentrations of calcium and magnesium. Their waters are very weakly buffered (Table 2). Concentration of soluble mineral salts in lake waters is extremely

Table 2. Physical and chemical features of investigated lakes

\begin{tabular}{|c|c|c|c|c|c|c|c|c|c|}
\hline \multirow{2}{*}{ Parameter } & \multirow{2}{*}{ Unit } & \multicolumn{3}{|c|}{ Lake Obrowo } & \multicolumn{3}{|c|}{ Lake Modre } & \multicolumn{2}{|c|}{ Lake Pomysko } \\
\hline & & epi- & meta- & hypo- & epi- & meta- & hypo- & epi- & meta- \\
\hline Color & {$\left[\mathrm{mg} \mathrm{Pt} \mathrm{dm}{ }^{-3}\right]$} & 5 & 7 & 9 & 8 & 10 & 22 & 7 & 10 \\
\hline $\mathrm{pH}$ & & 6.34 & 5.9 & 5.8 & 4.63 & 4.8 & 5.1 & 4.95 & 5.01 \\
\hline $\mathrm{BOD}_{5}$ & {$\left[\mathrm{mg} \mathrm{O}_{2} \mathrm{dm}^{-3}\right]$} & 1.2 & 1.6 & 1.2 & 0.2 & 1.4 & 3.1 & 0.2 & 0.8 \\
\hline $\mathrm{NH}_{4}$ & {$\left[\mathrm{mg} \mathrm{N} \mathrm{dm}^{-3}\right]$} & 0.18 & 0.16 & 0.58 & 0.38 & 0.25 & 0.52 & 0.33 & 0.43 \\
\hline $\mathrm{NO}_{3}$ & [mg N dm $\left.\mathrm{m}^{-3}\right]$ & nd & nd & 0.002 & 0.001 & 0.002 & 0.011 & 0.001 & 0.002 \\
\hline $\mathrm{NO}_{2}$ & {$\left[\mathrm{mg} \mathrm{N} \mathrm{dm}^{-3}\right.$ ] } & 0.04 & 0.06 & 0.09 & 0.09 & 0.08 & 0.09 & 0.06 & 0.09 \\
\hline $\mathrm{N}$ organic & [mg N dm$\left.{ }^{-3}\right]$ & 1.5 & 1.66 & 1.52 & 0.25 & 0.52 & 1.3 & 0.72 & 1.53 \\
\hline $\mathrm{N}$ total & {$\left[\mathrm{mg} \mathrm{N} \mathrm{dm}^{-3}\right]$} & 1.54 & 1.72 & 2.192 & 0.721 & 0.852 & 1.921 & 1.111 & 2.052 \\
\hline Sulphides & {$\left[\mathrm{mg} \mathrm{SO}_{4} \mathrm{dm}^{-3}\right]$} & 3 & 3 & 4 & 2 & 2 & 3 & nd & nd \\
\hline Chlorides & {$\left[\mathrm{mg} \mathrm{Cl} \mathrm{dm}^{-3}\right]$} & 8 & 7 & 8 & 5 & 5 & 5 & 5 & 5 \\
\hline TRP & {$\left[\mathrm{mg} \mathrm{P} \mathrm{dm}^{-3}\right]$} & 0.002 & 0.008 & 0.009 & 0.002 & 0.014 & 0.085 & 0.004 & 0.051 \\
\hline $\mathrm{P}$ total & {$\left[\mathrm{mg} \mathrm{P} \mathrm{dm}^{-3}\right]$} & 0.032 & 0.033 & 0.03 & 0.013 & 0.045 & 0.108 & 0.038 & 0.022 \\
\hline Alkalinity & {$\left[\mathrm{meq}^{-3} \mathrm{dm}^{-3}\right.$} & 0.05 & 0.09 & 0.76 & 0.03 & 0.04 & 0.05 & 0.03 & 0.03 \\
\hline Iron & {$\left[\mathrm{mg} \mathrm{Fe} \mathrm{dm}{ }^{-3}\right]$} & 0.37 & 0.47 & 0.92 & 0.34 & 0.58 & 1.6 & 0.37 & 0.63 \\
\hline Manganium & {$\left[\mathrm{mg} \mathrm{Mn} \mathrm{dm}{ }^{-3}\right]$} & 0.02 & 0.03 & 0.07 & 0.05 & 0.06 & 0.07 & 0.06 & 0.05 \\
\hline Potassium & {$\left[\mathrm{mg} \mathrm{K} \mathrm{dm}^{-3}\right]$} & 0.27 & nd & nd & nd & nd & nd & nd & 0.1 \\
\hline Sodium & {$\left[\mathrm{mg} \mathrm{Na} \mathrm{dm}^{-3}\right]$} & 1.9 & 1.7 & 1.7 & 1.1 & 1.1 & 1 & 1.4 & 1.4 \\
\hline Calcium & {$\left[\mathrm{mg} \mathrm{Ca} \mathrm{dm}^{-3}\right]$} & 3.4 & 4.3 & 6.3 & 2.4 & 2.4 & 3 & 0.85 & 1.17 \\
\hline Magnesium & {$\left[\mathrm{mgMg} \mathrm{dm}^{-3}\right]$} & 0.69 & 0.43 & 0.52 & 0.26 & 0.39 & 0.17 & 0.39 & 0.35 \\
\hline Conductivity & {$\left[\mu \mathrm{S} \mathrm{cm} \mathrm{cm}^{-1}\right]$} & 33 & 37 & 55 & 21 & 23 & 32 & 22 & 33 \\
\hline Chlorophyll-a & {$\left[\mu \mathrm{g} \mathrm{dm}^{-3}\right]$} & 0.14 & 0.78 & 12.65 & 1.14 & 2.74 & 5.3 & 1.04 & 18.28 \\
\hline
\end{tabular}


Table 3. Frequency (Fr) of all zooplankton species from among rotifers and crustaceans in the examined lakes

\begin{tabular}{lclll}
\hline \multicolumn{1}{c}{ Rotifera } & $\mathrm{Fr}$ & \multicolumn{1}{c}{ Crustacea } & $\mathrm{Fr}$ \\
\hline Keratella cochlearis (Gosse) & 100 & Ceriodaphnia quadrangula (O.F. Müller) & 100 \\
\hline Polyarthra vulgaris Carlin & 100 & Ceriodaphnia pulchella Sars & 88 \\
\hline Kellicottia longispina (Kellicott) & 75 & Eudiaptomus gracilis (Sars) & 88 \\
\hline Trichocerca similis (Wierzejski) & 75 & Alonella nana (Baird) & 50 \\
\hline Keratella quadrata (O.F. Müller) & 63 & Diaphanosoma brachyurum (Lievin) & 38 \\
\hline Trichocerca insignis (Herrick) & 63 & Bosmina coregoni Baird & 38 \\
\hline Gastropus stylifer Imhof & 50 & Bosmina longispina Leydig & 25 \\
\hline Asplanchna priodonta Gosse & 38 & Alona affinis (Leydig) & 25 \\
\hline Collotheca mutabilis (Hudson) & 38 & Alona rustica Scott & 25 \\
\hline Conochilus unicornis (Rousselet) & 38 & Alonella exigua (Lilljeborg) & 25 \\
\hline Ascomorpha ovalis (Bergendahl) & 25 & Daphnia galeata Sars & 25 \\
\hline Keratella serrulata (Ehrenberg) & 25 & Holopedium gibberum Zaddach & \\
\hline Lepadella patella (O.F. Müller) & 25 & Heterocope appendiculata Sars & \\
\hline Polyarthra remata (Skorikov) & 25 & Chydorus sphaericus (O.F. Müller) & \\
\hline Trichocerca rousseleti (Voigt) & 25 & Graptoleberis testudinaria (Fischer) & \\
\hline Cephalodella sp. & 13 & & \\
\hline Filinia opoliensis (Zacharias) & 13 & & \\
\hline Lecane lunaris (Ehrenberg) & 13 & & \\
\hline Ploesoma hudsoni (Imhoff) & 13 & & \\
\hline Testudinella parva (Ternetz) & 13 & & \\
\hline Trichocerca pusilla Lauterborn & 13 & & \\
\hline
\end{tabular}
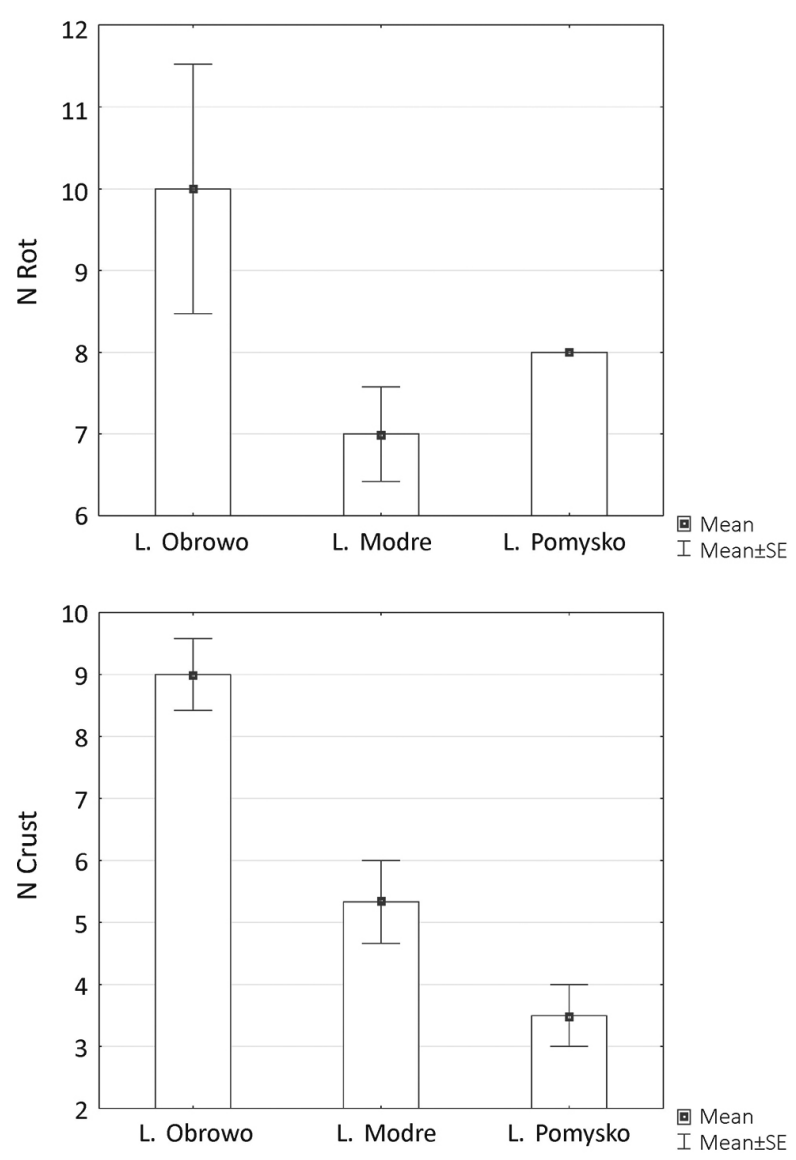

Fig. 2. The mean number of species (from all water layers) of rotifer (N Rot) and crustaceans (N Crust) in the examined lakes low (electrical conductivity in the epilimnion layer is below $30 \mu \mathrm{Sm} \mathrm{cm} \mathrm{cm}^{-1}$ ) because the lakes are supplied mainly by rain and penurious surface runoff from forested catchment. The concentration of nitrogen and phosphorus is also very low. However, some differences in water chemistry exist between the lakes. Lakes Pomysko and Modre are highly acidic - $\mathrm{pH}$ in almost the whole water column is below 5 while the water of Obrowo lake is only slightly acidic. Low concentrations of nutrients result in very low concentrations of phototosynthetic pigment chlorophyll- $a$ (in epilimnetic waters only about $1 \mu \mathrm{g}$ per litre was found).

In the three lobelia lakes 36 zooplankton species in total (21 Rotifera, 15 Crustacea among which 13 Cladocera and 2 Copepoda), representing 26 genera, were identified. Only $22 \%$ of the taxonomical structure was common for all lakes $(24 \%$ within rotifers and $20 \%$ within crustaceans). In each water body, rotifers had more diverse communities than crustaceans, however, in Obrowo and Modre crustaceans also had a high taxonomic diversity.

In the taxonomic structure we found species that are rare for the Polish fauna, such as Filinia opoliensis, Holopedium gibberum and Heterocope appendiculata (Table 3).

The most common species, i.e. species that occurred in $\geq 50 \%$ of samples, were Keratella cochlearis, Polyarthra vulgaris, Kellicottia longispina, Trichocerca similis, Keratella quadrata, Trichocerca insignis and Gastropus stylifer from among rotifers as well as Ceriodaphnia 

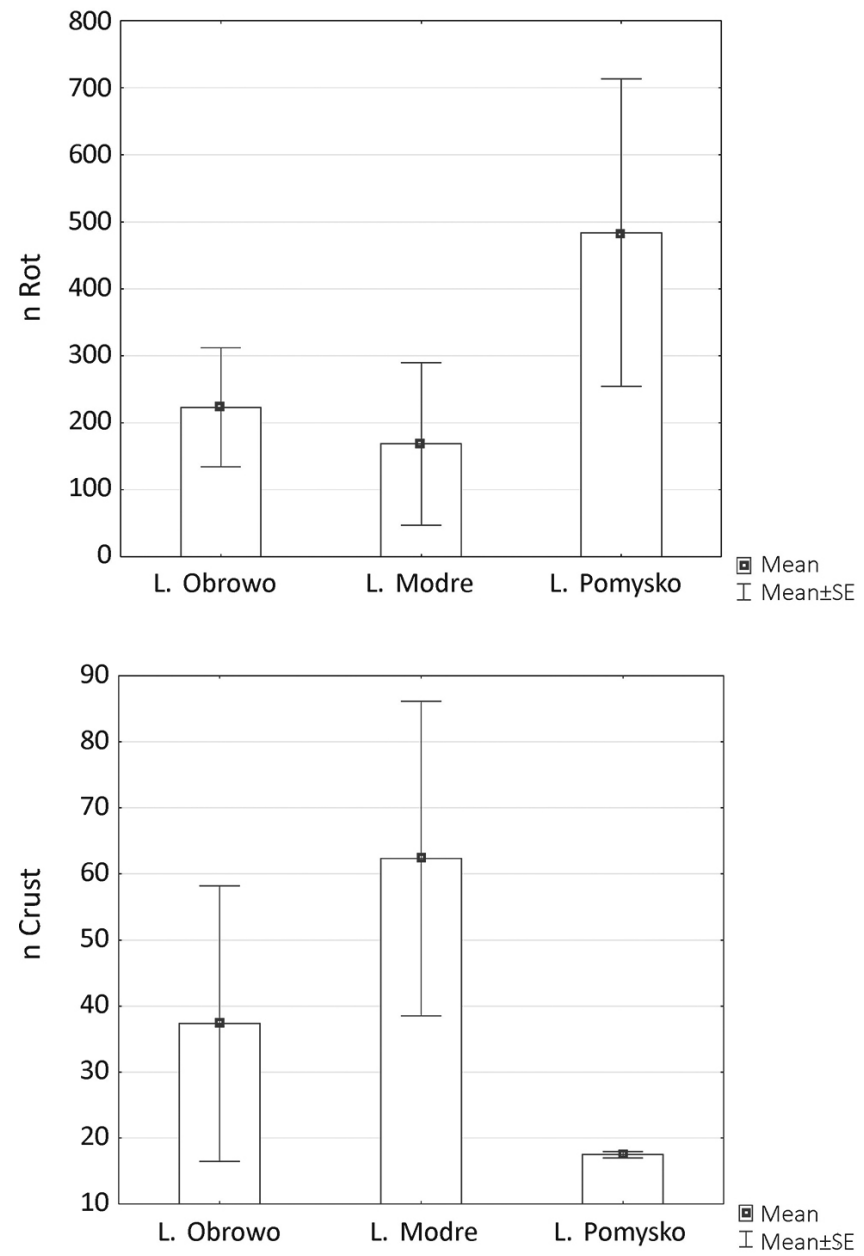

Fig. 3. Abundance (ind. $\mathrm{dm}^{-3}$ ) of rotifer (n Rot) and crustaceans (n Crust) in the examined lakes

guadrangula, Ceriodaphnia pulchella, Eudiaptomus gracilis, Alonella nana and Diaphanosoma brachyurum from among crustaceans (Table 3 ).

The total species richness varied between the lakes with the lowest values obtained for Pomysko with 16 species (11 Rotifera, 5 Crustacea) and higher for Modre (11 Rotifera, 9 Crustacea) and particularly for Obrowo lake (14 Rotifera, 12 Crustacea).

The mean number of zooplankton species was also highest, for both rotifers and crustaceans, in Obrowo lake. The lowest mean species composition was found in Modre lake for rotifers and in Pomysko lake in the case of crustaceans. Only for crustaceans were the differences significantly different $(\mathrm{H}=6.01 ; \mathrm{p}<0.05)$ (Fig. 2).

Zooplankton densities reached a level of between 235 and 506 ind $\mathrm{dm}^{-3}$, depending on the lake. No significant differences were found between the three lakes, however, Pomysko had highest rotifer densities, while Modre lake had the highest abundance of crustaceans (Fig. 3). Rotifera dominated over Cladocera and Co-
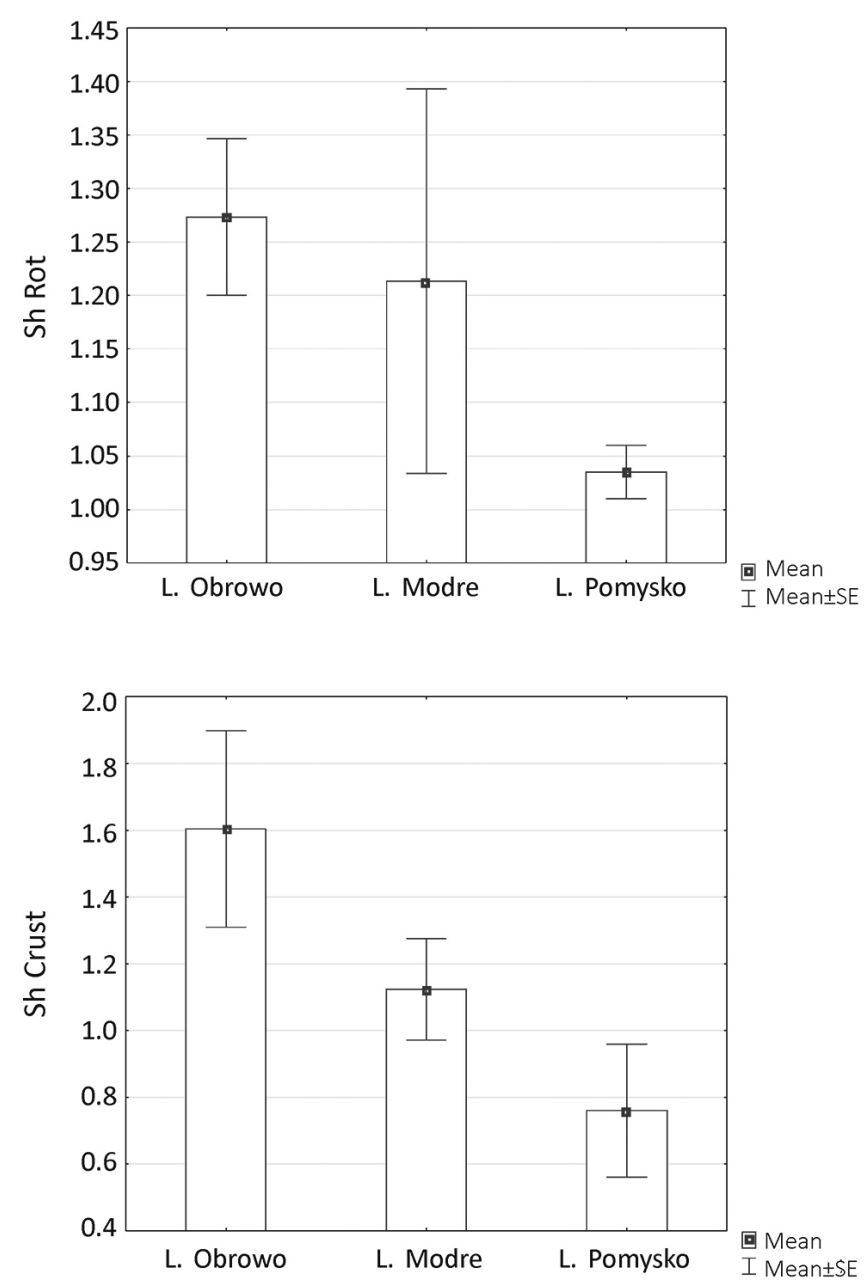

Fig. 4. The Shannon-Weaver index of rotifer (Sh Rot) and crustaceans (Sh Crust) in the examined lakes

pepoda in all lakes, comprising between $72 \%$ in Modre lake up to $96 \%$ in Pomysko.

The Shannon-Weaver index reached values between 1.02 and 1.55 , depending on group of zooplankton and lake. The highest values were obtained for Obrowo lake, for both rotifers and crustaceans, while the lowest for Pomysko. However, the diversity index did not reveal any significant variation between particular lakes (Fig. 4).

PCA analysis performed for zooplankton dominating species showed a clear separation of species in reference to lakes and environmental factors (Fig. 5). In Pomysko Lake, an association between three rotifers (Polyarthra remata, Polyarthra vulgaris, Trichocerca insignis) and total nitrogen as well as chlorophyll a concentration was observed. Conversely, a decreasing content of total nitrogen as well as chlorophyll a positively affected the abundance of both rotifers (Conochilus unicornis, Kellicottia longispina, Keratella cochlearis, Keratella quadrata) and crustaceans (Bosmina long- 


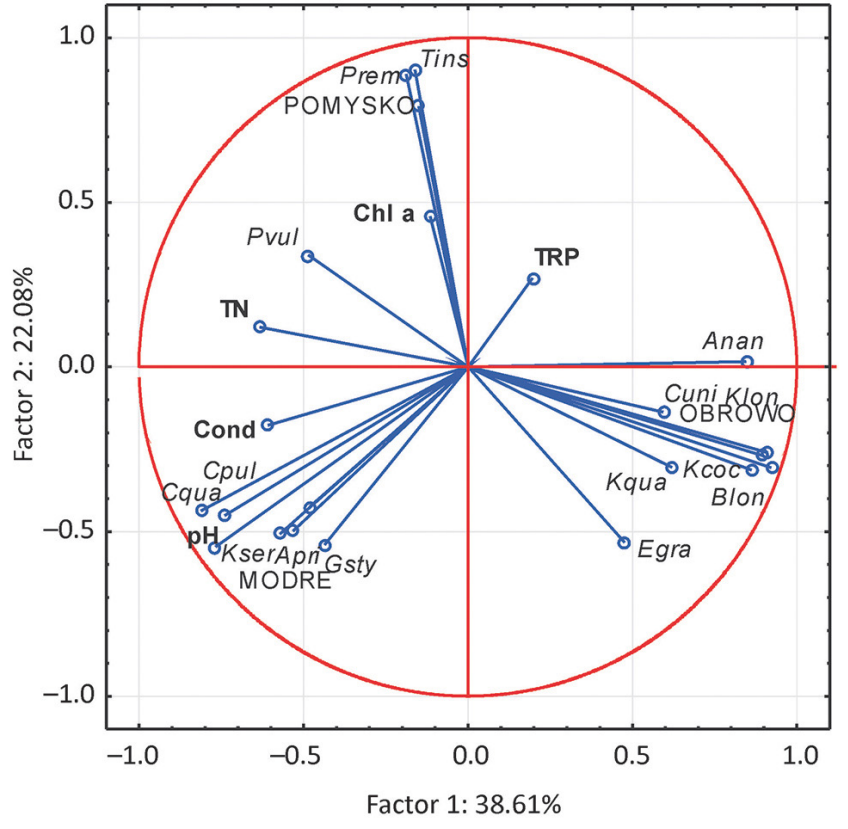

Fig. 5. Principal component analysis (PCA) with abundance of zooplankton dominating species (Apri - Asplanchna priodonta; Cuni - Conochilus unicornis; Gsty - Gastropus stylifer; Klon - Kellicottia longispina; Kcoc - Keratella cochlearis; Kqua - Keratella quadrata; Kser - Keratella serrulata; Prem - Polyarthra remata; Pvul - Polyarthra vulgaris; Tins - Trichocerca insignis; Anan - Alonella nana; Blon - Bosmina longispina; Cqua - Ceriodaphnia quadrangula; Cpul - Ceriodaphnia pulchella; Egra - Eudiaptomus gracilis) and environmental factors (Chl a - chlorophyll- $a$ concentration, TN - total nitrogen, TRP - total reactive phosphorus, Cond - conductivity, $\mathrm{pH}$ ) and lakes

ispina, Eudiaptomus gracilis) in Obrowo lake. Finally, in Modre lake the abundance of rotifers (Asplanchna priodonta, Gastropus stylifer, Keratella serrulata) and crustaceans (Ceriodaphnia quadrangula, Ceriodaphnia pulchella) rose with increasing water reactivity and conductivity (Fig. 4).

\section{Discussion}

Even though the three examined lakes are located close to each other, of the same origin, and generally similar according to morphological as well as physical and chemical water characteristics, zooplankton community structure differed greatly in respect to species composition, the occurrence of inhabiting species and also in the abundance of rotifer and crustacean communities. The most frequent species in the samples were both rotifers and crustaceans that are described in the literature as very common, occurring in various water bodies in many continents, such as e.g. Keratella cochlearis, Polyarthra vulgaris, Kellicottia longispina, Trichocerca similis, Keratella quadrata, Trichocerca insignis or Gastropus stylifer from among rotifers or Ceriodaphnia quadrangula, Ceriodaphnia pulchella and Eudiaptomus gracilis from among crustaceans. Two of these species, Kellicottia longispina and Gastropus stylifer, are designated as indicators of low trophic state (Radwan et al. 2004), which confirms the generally good quality of these lakes, despite the fact that they differ slightly according to the concentration of available forms of nitrogen and phosphorus. The most frequent species in the three lakes belong to typically pelagic species (Flössner 1972; Radwan et al. 2004; Błędzki and Rybak, 2016).

Generally good quality of water in the examined lakes was also proved by the occurrence of species such as Filinia opoliensis, Holopedium gibberum and Heterocope appendiculata, which are identified to be rare in the Polish fauna (Radwan et al. 2004; Kraska et al. 2006; Bielańska-Grajner et al. 2017). The occurrence of these species in the studied lobelia lakes was connected with their ecological requirements towards specific conditions such as cold and low-trophy waters of low hardness and low water pH (Flössner 1972; Nyberg 1995; Czeczuga and Kozłowska 2002; Podshivalina et al. 2012; Ejsmont-Karabin and Karabin 2013). Moreover, the literature data states that in the case of crustaceans (Holopedium gibberum and Heterocope appendiculata), their presence and/or disappearance in many lakes may also be connected with changes in the biotic relationships, especially with the predation pressure caused by biomanipulation with fish (e.g. Stenson 1973; Popadin 2002).

Obrowo lake had the most diverse community of both rotifers and crustaceans. The Shannon-Weaver index was also highest compared to the other lakes Modre and Pomysko. In this lake we found that decreasing concentrations of total nitrogen and chlorophyll- $a$ contributed to the decrease of zooplankton abundance. Our study indicates that the diversity of zooplankton assemblages is inversely proportional to the human impact on lakes. In the typology of Polish lobelia lakes taking into account the reference state and symptoms of deviations from this state - Obrowo lake is classified in the group of "balanced" lobelia lakes, without symptoms of anthropopression. Lakes Modre and Pomysko are both lobelia ecosystems which exhibit symptoms of water dystrophication - lower water $\mathrm{pH}$ (Klimaszyk et al. 2016). Furthermore, Modre lake is under moderate recreational use and there is data which indicate that it was limed and fish stocked (Kraska et al. 2013), while in the case of Pomysko part of the shoreline was developed into a recreational centre.

Zooplankton abundance was generally at a low level in all three lakes, between 200 and 500 ind. $\mathrm{dm}^{-3}$, indicating considerably good quality of water, as the community densities can also be a proper indicator of trophic conditions in lakes (e.g. Špoljar et al. 2011; 
Tasevska et al. 2017). Rotifers dominated over crustaceans, which suggests the presence of fish in all the water bodies (Helenius et al. 2015). The highest share of rotifers was found in Pomysko Lake;,rising contents of total nitrogen as well as chlorophyll a had a positive impact on the densities of some rotifer species (Polyarthra remata, Polyarthra vulgaris, Trichocerca insignis) in this lake. In Obrowo lake the opposite effect was observed when the fall in the concetration of total nitrogen and chlorophyll- $a$ increased the abundance of both groups of zooplankton - rotifers (e.g. Conochilus unicornis, Keratella cochlearis) and crustaceans (e.g. Eudiaptomus gracilis). In the last lobelia lake - Modre - the abundance of zooplankton (e.g. Asplanchna priodonta, Gastropus stylifer from among rotifers and Ceriodaphnia quadrangula from among crustaceans) was positively affected an increase in water reactivity and conductivity.

\section{Conclusions}

Even though lobelia lakes are ecosystems that undergo anthropogenic impact, reflected in an increase of algae biomass, nutrient concentration and decrease of water transparency, they are still taxonomically very variable water bodies. The observed symptoms of deterioration of water quality, which was reflected in the zooplankton community indices (e.g. in species composition, the Shannon-Weaver index or the occurrence of rare species for the Polish fauna), showed that best conditions prevailed in Obrowo lake compared to two remaining lakes - Modre and Pomysko.

\section{References}

[APHA] American Public Health Association, 1992, Standard methods for water and wastewaters analyzing, Am. Publ. Health Assoc., New York.

Bielańska-Grajner I., Sowa A., Pasamonik A., Pielok K., Kolek L., 2017, Nowe stanowisko rzadkiego gatunku wrotka Filinia opoliensis w południowej Polsce (A new record of the rare rotifer species Filinia opoliensis in Southern Poland), Chrońmy Przyr. Ojcz. 73(2): 151-154 (in Polish, English summary).

Błędzki L., Rybak J.I., 2016, Freshwater Crustacean Zooplankton of Europe: Cladocera \& Copepoda (Calanoida, Cyclopoida) Key to species identification, with notes on ecology, distribution, methods and introduction to data analysis, Springer, $918 \mathrm{pp}$.

Bociąg K., Rekowska E., Banaś K., 2011, The disappearance of stonewort populations in lobelia lakes of the Kashubian Lakeland (NW Poland), Ocean. Hydrobiol. Stud. 40(2): 30-36.

Czeczuga B., Kozłowska M., 2002, Fertility of Eudiaptomus, Bosmina and Daphnia (Crustacea) representatives in lakes of varied trophic states in the Suwałki district, Pol. J. Environ. Stud. 11(1): 23-31.

Ejsmont-Karabin J., Karabin A., 2013, The suitability of zooplankton as lake ecosystem indicators: crustacean trophic state index, Pol. J. Ecol. 61(3): 561-573.

Flössner D., 1972, Krebstiere, Crustacea: Kiemen- und Blattfusser, Branchiopoda, Fischläuse, Branchiura. Tierwelt Deutschl. 60, VEB Gustav Fisher Verlag, Jena, 499 pp (in German).

Helenius L.K., Padrós A.A., Leskinen E., Lehtonen H., Nurminen L., 2015, Strategies of zooplanktivory shape the dynamics and diversity of littoral plankton communities: a mesocosm approach, Ecol. Evol. 5(10): 2021-2035.

Koff T., Vandel E., Marzecová A., Avi E., Mikomägi A., 2016, Assessment of the effect of anthropogenic pollution on the ecology of small shallow lakes using the palaeolimnological approach, Est. J. Earth. Sci. 65(4): 221-233.

Klimaszyk P., Kraska M., Piotrowicz R., 2016, Polish lobelian lakes evolution and protection, Proc. of the International Conference "Lakes, Reservoirs and Ponds: Impacts - Threats - Conservation", Iława Poland, 31 May-3 June, Wydaw. UMK, Toruń: 219-224.

Kraska M., Klimaszyk P., Piotrowicz R., 2013, Anthropogenic changes in properties of the water and spatial structure of the vegetation of the lobelia lake Lake Modre in the Bytów Lakeland, Oceanogr. Hydrobiol. Stud. 42(3): 302-313.

Kraska M., Piotrowicz R., 2000, Jeziora lobeliowe: specyfika, trofia, roslinność i problemy ochrony (Lobelia lakes: specifty, trophy, vegetation and problems of the preservation), [in:] Ochrona jezior i mokradeł Pomorza Środkowego (Preservation of lakes and bogs of the Central Pomerania) Tow. Ekologiczno-Kulturalne w Bobolicach, Bobolice Biul. 3: 5-27 (in Polish).

Kraska M., Piotrowicz R., Klimaszyk P., 1996, Jeziora lobeliowe w Polsce (Lobelia lakes in Poland), Chrońmy Przyr. Ojcz. 52(3): 5-25 (in Polish, English summary).

Kraska M., Piotrowicz R., Klimaszyk P., Kuczyńska-Kippen N., Szeląg-Wasielewska E., 2006, Biodiversity in three lobelian lakes in relation to the catchment area influence, Acta Agrophys. 7(2): 401-413.

Margalef R., 1957, Information theory in ecology, Gen. Syst. 3: $36-71$.

Nyberg P., 1995, Liming strategies and effects: the Lake Västra Skälsjön case study, [in:] Henrikson L., Brodin Y.W. (eds) Liming of acidified surface waters, Springer, Berlin-Heidelberg 327-338.

Podshivalina V.N., Sheveleva N.G., Bayanov N.G., 2012, Biology and Ecology of Holopedium gibberum (Branchiopoda: Cladocera: Ctenopoda) in the Palearctic, Hydrobiol. J. 48(6): 28-36.

Popadin K., 2002, Body size of Holopedium gibberum under the influence of fish predation in small subarctic lakes, Verh. Int. Verein. Limnol. 28: 1-6.

Radwan S., Bielańska-Grajner I., Ejsmont-Karabin J., 2004, Rotifers Rotifera. Freshwater fauna of Poland. Vol. 32, Oficyna Wydaw. Tercja, Łódź, 447 pp. 
Ruoppa M, Heinonen P., Pilke A., Rekolainen S., Toivonen H., Vuoristo H. (eds.), 2003, How to assess and monitor ecological quality in freshwaters, Nordic Council of Ministers, Copenhagen, $214 \mathrm{pp}$.

Špoljar M., Tomljanović T., Lalić I., 2011, Eutrophication impact on zooplankton community: A shallow lake approach, Holist. Approach Environ. 1(4): 131-142.

Stenson J.A.E., 1973, On predation and Holopedium gibberum (Zaddach) distribution, Limnol. Oceanogr. 18(6): 1005-1010.
Szeroczyńska K., Zawisza E., 2011, Subfossil faunal and floral remains (Cladocera, Pediastrum) in two northern Lobelia lakes in Finland, Knowl. Manag. Aquat. Ecosyst. 402: 09.

Szmeja J., 1996, Evolution and conservation of lobelia lakes in Poland, Fragm. Flor. Geobot. 42(1): 89-94.

Tasevska O., Špoljar M., Gušeska D., Kostoski G., Patcheva S., Veljanoska Sarafiloskav E., 2017, Zooplankton in ancient and oligotrophic Lake Ohrid (Europe) in association with environmental variables, Croat. J. Fish. 75: 95-103. 